\title{
Employee Performance Improvement Through Competence and Organizational Culture with Work Motivation as A Mediation Variable
}

\author{
Wahyu Apri Nurasniar ${ }^{1}$ \\ 1 Universitas Sultan Ageng Tirtayasa \\ 1JI. Raya Palka No.Km 3, Panancangan, Kec. Cipocok Jaya, Serang, Banten 42124 \\ e-mail: apreenoer@gmail.com ${ }^{1}$
}

\begin{abstract}
To cite this document :
Nurasniar, A.W., (2022). Employee Performance Improvement Through Competence and Organizational Culture with Work Motivation as A Mediation Variable. Aptisi Transactions on Management (ATM), 6(2), 121-131.
\end{abstract}

DOI :

https://doi.org/10.33050/atm.v6i2.1743

\begin{abstract}
The performance of employees in government organizations must constantly be improved based on their function as public servants so that government organizations will be able to provide the best service to the needs of the public. This study aimed to examine the effect of competence, organizational culture, and work motivation on improving employee performance. The novelty in this research is that no previous research has been found that discusses improving employee performance through the influence of competence, organizational culture, and work motivation on employees' section of Bina Marga. The limitation in this study is only to analyze the magnitude of the influence of competence, organizational culture, and work motivation on the employee performance section in Bina Marga. The method used in this study is quantitative. The population and sample of this study were all employees in the Highways Sector as many as 40 people. The data collection technique used a questionnaire with a Likert scale ranging from 1 to 10. Structural Equation Modeling was used to test the statistical significance of the path coefficients. The result of this research is that there is a positive and significant influence between competence on work motivation. Competence has a positive and significant influence on employee performance. Organizational culture has a positive and significant influence on employee performance. Work motivation does not affect employee performance
\end{abstract}

Keywords: Competence, Organizational Culture, Work Motivation, Employee Performance

\section{Introduction}

Human resources are the most critical factor in an organization. With the resources owned, an organization will be able to develop continually. Organizations that have quality human resources will be able to achieve the goals that have been set.

Currently, government performance is always in the public spotlight, so the performance of employees in government organizations is constantly improved. Based on its function as a public servant, government organizations will always try to provide the best service to the community's needs.

The implementation of government bureaucratic reform will run well if it begins with adequate human resources. The main task of government employees is to provide excellent service to the community and support the development that has been carried out. Government employees have roles in implementing laws and regulations, carrying out public service functions, government managers, organizational leaders, asset managers, and state/regional finance. 
The performance problems of government employees until now are always considered not as expected. The performance of government employees in carrying out their duties has not been optimal, as indicated by the community's assessment of the services provided. Based on this, the government continues to improve employee performance comprehensively.

Factors that can improve employee performance are competence, organizational culture, and motivation. Employee performance is highly dependent on the competence of each individual. Government employees must also have high competence in carrying out their duties as public servants.

Competence is an individual's ability to carry out a job correctly and has advantages based on matters relating to knowledge, skills, and attitudes [1]

Organizational culture is the result of merging the artistic style and or behavior of each individual that was brought before into a new norm and philosophy, which has the energy and pride of the group in dealing with certain things and goals. [2]

Problems related to an organizational culture that arise in government organizations include the lack of cooperation between employees to affect the performance of the employees themselves. Therefore, motivation is needed so that employees are more enthusiastic in carrying out their work activities. With motivation, it is expected to change employee behavior for the better and ultimately improve employee performance.

Public service motivation (PSM) is one of the distinctive forms or parts of motivation which can be defined as motivation that includes beliefs, values, and attitudes that go beyond personal interests and organizational interests, encouraging an employee (employee) to do good to others and donate their service to the welfare of the organization and society. [3]

Based on the existing phenomenon about the importance of improving the performance of government employees to provide excellent service to the community, the researchers are interested in conducting research and testing on competence, organizational culture. They work motivation to improve employee performance in government agencies.

\section{Theoretical Foundation \\ 2.1 Competence}

Sutrisno defines competence as an ability based on skills and knowledge supported by work attitudes and their application in carrying out tasks and work in the workplace that refers to the work requirements set competence. [4]

Competence is a fundamental factor in someone with more abilities and makes it different from other people who have average abilities.[5]

Competence is a person's ability or capacity to perform various tasks in a job, where intellectual and physical factors determine this ability.[6]

Work competence is the workability of each individual, which includes aspects of knowledge, skills, and work attitudes by predetermined standards (UU No.13 Tahun 2003 tentang Ketenagakerjaan). Competence is the specification of knowledge and skills and applying this knowledge and skills in a job or company or across industries by the required performance standards. Competence is broadly divided into two, namely technical competence and non-technical competence. Technical competence can be measured through 1) level of education, 2) work experience, and 3) the ability to analyze. Meanwhile, non-technical competence can be measured through 1) Self-Control; 2) Confident; 3) Flexibility; and 4) Attitude. [7]

\subsection{Organizational culture}

According to Harwiki, the definition of organizational culture is a system of values, beliefs, assumptions, or norms that have been going on for a long time, agreed upon, and followed by members of an organization as a guide for behavior and solving organizational problems.[8] Organizational culture is also known as corporate culture. Organizational culture.

The characteristics of organizational culture that can be used as indicators of organizational culture are as revealed by Robbins. [9]

a. Innovation and risk-taking, namely the extent to which organizational members are encouraged to be innovative and take risks.

b. Attention to detail, namely the extent to which members of the organization are expected to show accuracy, analysis, and attention to detail.

c. Outcome orientation, namely the extent to which management focuses on the results, techniques, and processes used to achieve those results. 
d. People Orientation (Orientation of people), namely the extent to which management decisions influence organization members.

e. Team Orientation, namely the extent to which work activities are organized into teams, not individuals.

f. Aggressiveness (Aggressiveness), namely members of the organization, are competitive, aggressive, and not relaxed.

g. Stability, namely the extent to which organizational activities emphasize maintaining the status quo rather than growth.

\subsection{Work motivation}

According to Bauman [10], in I Ketut Setia SAPTA [11], motivation is a series of attitudes and values that can influence individuals in achieving specific tasks according to individual goals.

Motivation is the primary drive that drives a person to behave and do something according to his impulse. Motivation can also be interpreted as a process that seeks to influence the person or people who are led to do the desired work based on specific goals. [12]

Indicators of work motivation based on Abraham Maslow's hierarchy of needs theory in Eni Wuryani are [13]:

a. Physical Needs. It is a basic human need that can be food, drink, rest, biological needs, and others.

b. Safety and Security Needs. After physical needs, the following need as security, health insurance, job security guarantees, and retirement benefits

c. Social Needs. Social needs are needs A and are accepted by the social environment. Examples of compact workgroups, good relationships between individuals, and friendship.

d. Appreciation Needs. This need is in the form of appreciation for employees who excel in recognizing their abilities and expertise.

e. Self-Actualization Needs. A need lies in the placement of individuals in the environment and self-development, which can be in the form of clear career development/paths, giving promotions or promotions to employees who excel, or involving employees in various activities that have challenges.

\subsection{Employee Performance}

According [14] to argues that performance is the result of work in quality and quantity achieved by an employee in carrying out his duties by the responsibilities given to him.

Performance is the result of work that employees can achieve, both individuals and groups in an organization, the authority and responsibility given by the organization in achieving the vision and mission, and goals of the organization with the ability to solve problems following the specified time not violating the law [15]. Employee performance indicators, according to Robbins, [16] are as follows:
1) Quality
2) Quantity
3) Punctuality
4) Effectiveness
5) Independence 


\subsection{Framework}

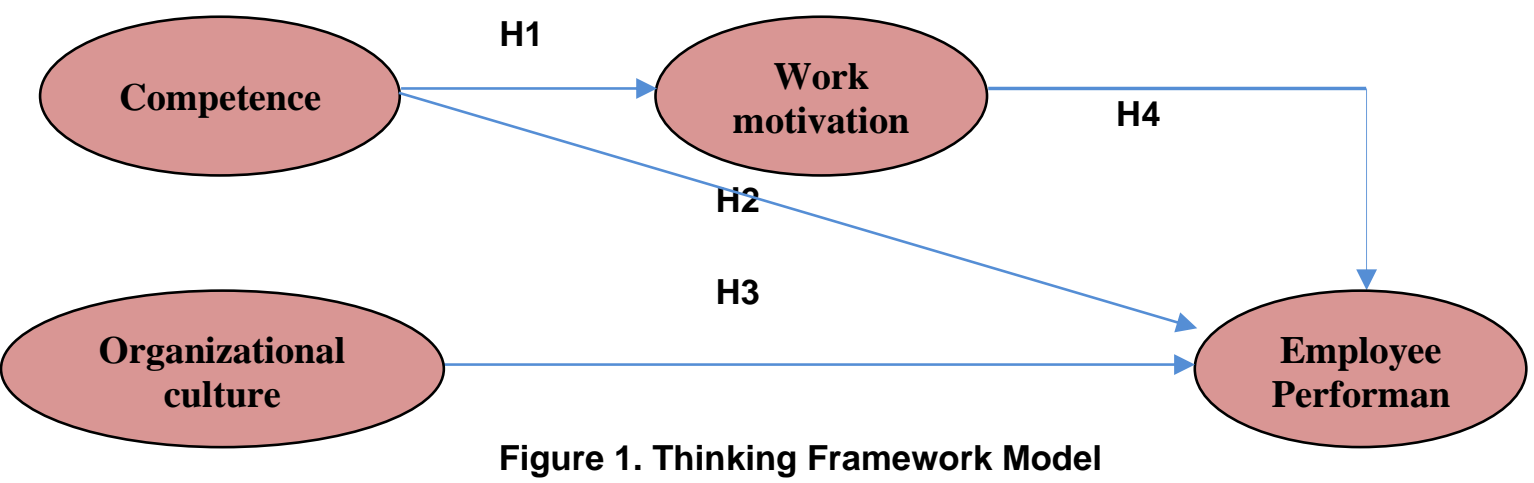

\subsection{The Effect of Competence on Work Motivation}

One of the things related to work motivation is competence. Competence is the ability to carry out work based on skills and insight and is supported by a good work attitude. Competence has a positive and significant effect on work motivation [17] . There is a positive and significant influence between competence on motivation [18]. From the results of previous studies, the researchers formulated the hypothesis in this study as follows:

$\mathrm{H} 1$ : Competence has a positive and significant effect on work motivation

\subsection{The Effect of Competence on Employee Performance}

In achieving organizational goals, employee competence will affect employee performance. There is a significant influence between employee competence on employee performance [19]. The results of Wahyudi's [20] research state that competence has a positive effect on performance. From the results of previous studies, the researchers formulated the hypothesis in this study as follows:

$\mathrm{H} 2$ : Competence has a positive and significant effect on employee performance

\subsection{The Influence of Organizational Culture on Employee Performance}

A strong organizational culture will affect the performance of its employees, either in the form of technical ability, conceptual ability, responsibility, initiative, and interpersonal relationship skills. Organizational culture has a significant direct effect on performance [21], Work culture has a positive and significant effect on performance [22]. From the results of previous studies, the researchers formulated the hypothesis in this study as follows:

H3: Organizational Culture has a positive and significant effect on employee performance

\subsection{The Effect of Work Motivation on Employee Performance}

Work motivation has a relationship and affects employee performance; this statement is per research conducted by Achmad [23], which states that motivation significantly affects employee performance. Research conducted by Yulius Dharma [24] states that there is an influence of motivation on employee performance.

High employee motivation will affect employee performance, both individual, group, and organizational performance [25]

$\mathrm{H} 4$ : Work motivation has a positive and significant effect on employee performance

\section{Research Method}

The research method used in this research is quantitative. The population of this research is employees at the Department of Public Works and Spatial Planning of Cilegon City, Bina Marga Sector. The sample in this study were all employees in the Highways Sector, as many as 40 people. The analytical tool used is Structural Equation Modeling (SEM) using the SmartPLS program. Data collection method by distributing closed questionnaires to respondents. Measurement of the questionnaire using a Likert scale from 1 (strongly disagree) to 10 (strongly agree)Tables and Figures are presented center, as shown below and cited in the manuscript. 


\section{Research Result}

\subsection{Validity Results (Initial Outer Model)}

Evaluation of the measurement model or outer model is carried out to assess the validity and reliability of the model (Imam Ghozali and Hengky Latan, 2015). In this analysis, we will see the effect of Loading Factor, Average Variance Extracted (AVE), Discriminant Validity, and Composite Reliability.

\subsection{Construct Validity Test}

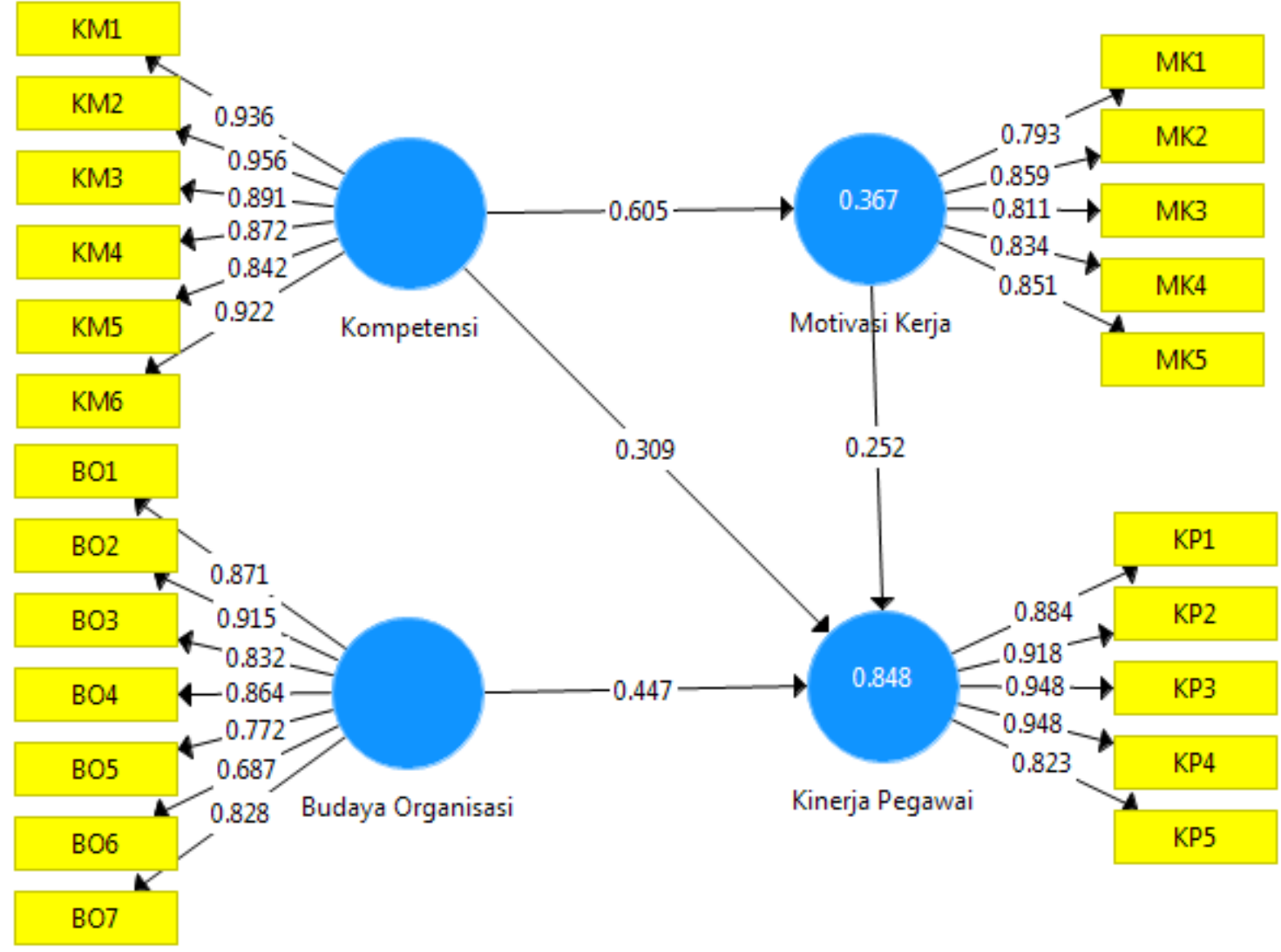

Figure 2. Results of the Preliminary Model Analysis of the PLS Algorithm Source: Research Data Processing, 2021

Indicators that are declared to meet the validity can be seen from the value of the loading factor for each construct indicator. The rule of thumb commonly used to test the validity is the loading factor value $>0.7$ [26]. Based on Figure 2. The results of the initial model analysis of the PLS Algorithm indicate that some indicators have a loading factor value below 0.7, namely BO6 (Organizational Culture Variable with Aggressiveness/Aggressiveness indicator) with a loading factor value of 0.687 must be removed. 


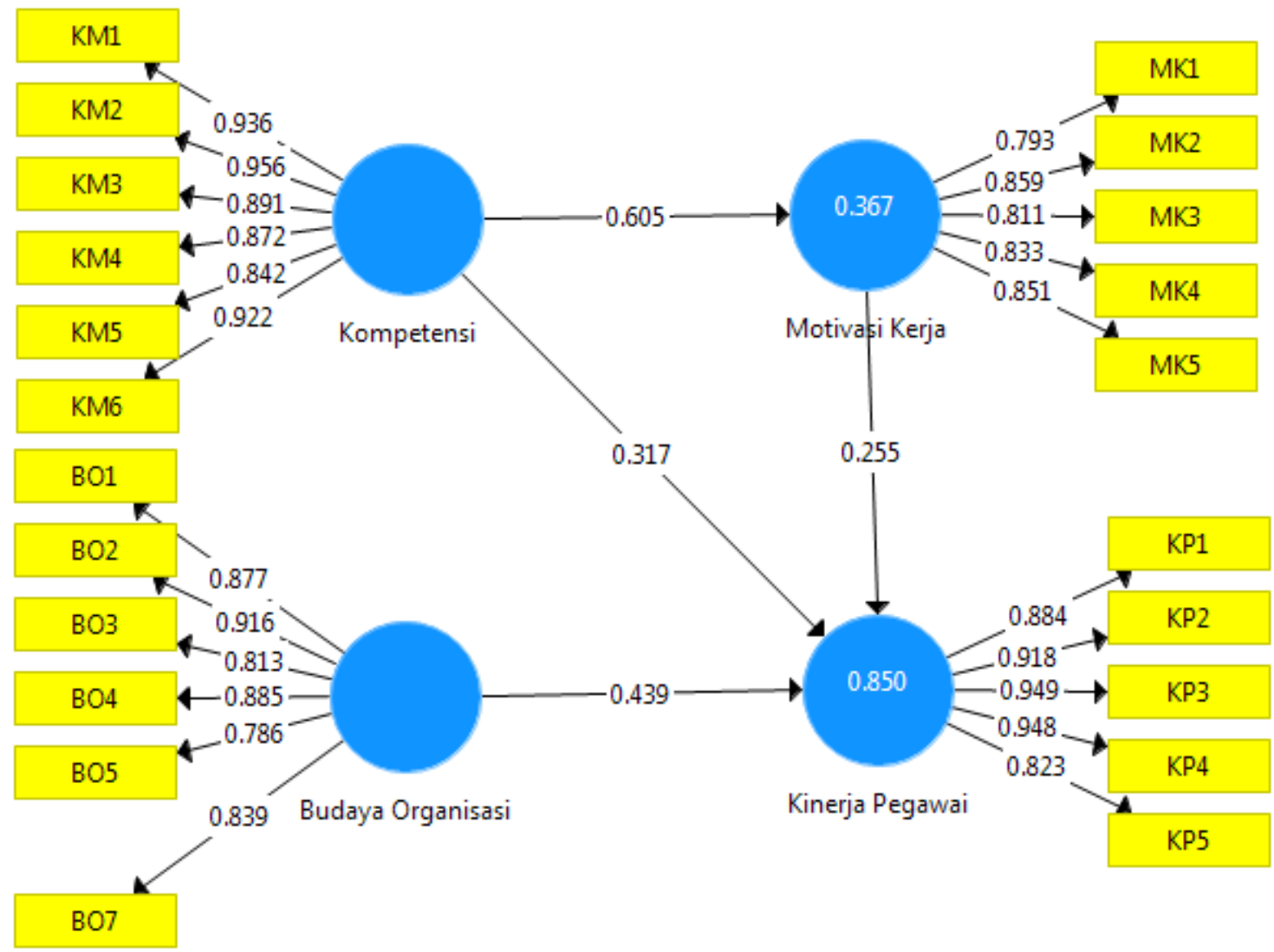

Figure 3. Results of the Final Model Analysis of the PLS Algorithm Source: Research Data Processing, 2021

Based on Figure 3, after the indicator that has a loading factor value of $<0.7$ is removed, it is obtained that all indicators meet the validity test because they have a loading factor value of $>$ 0.7 , and then a bootstrapping analysis is carried out with the results in Figure 4. 


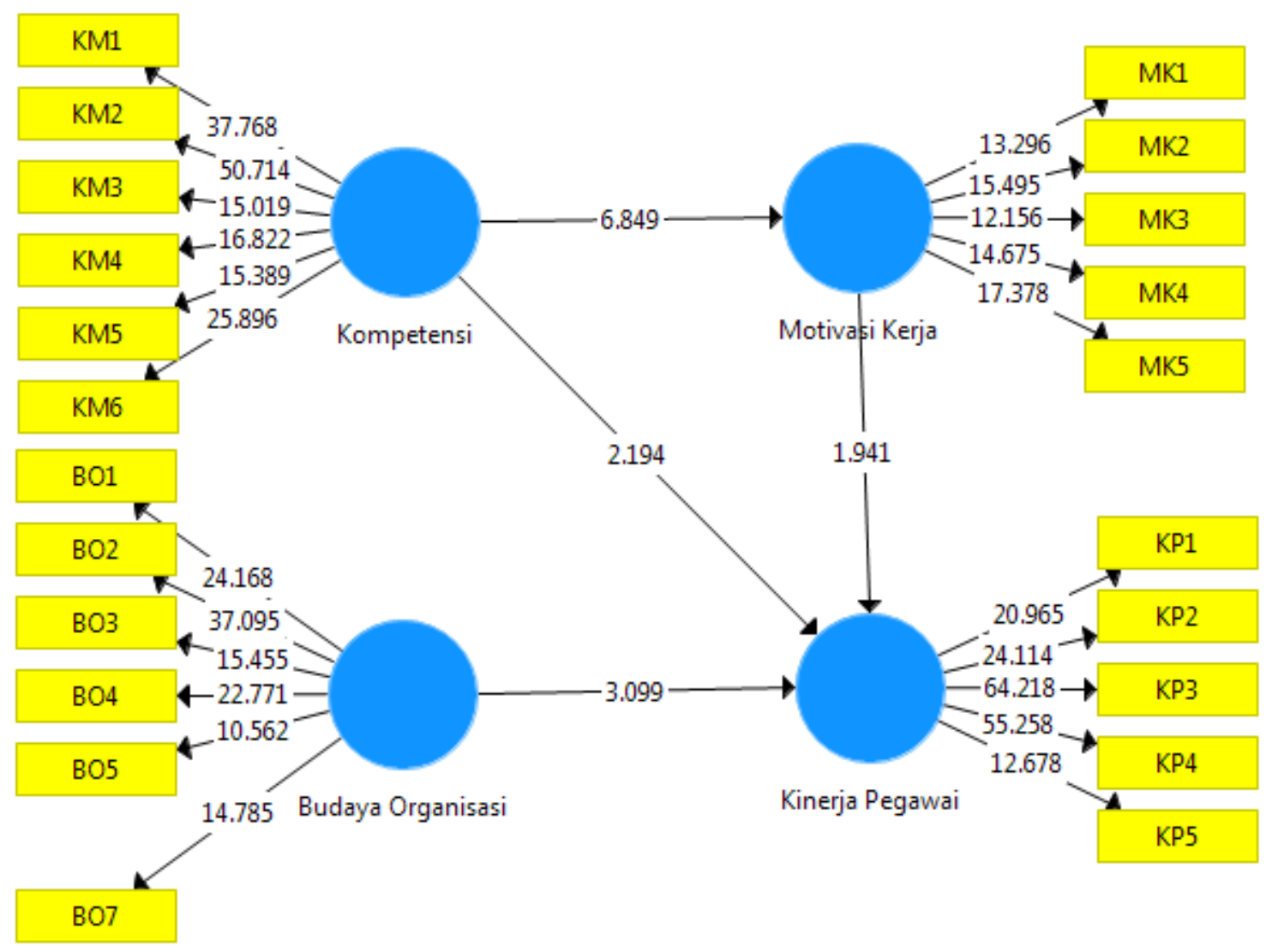

Figure 4. Results of the PLS Bootstrapping Analysis Model Source: Research Data Processing, 2021

\subsection{Construct Reliability Test}

\begin{tabular}{|l|r|r|r|r|}
\hline & $\begin{array}{c}\text { Cronbach's } \\
\text { Alpha }\end{array}$ & \multicolumn{1}{|c|}{ rho_A } & $\begin{array}{c}\text { Reliabilitas } \\
\text { Komposit }\end{array}$ & $\begin{array}{c}\text { Rata-rata } \\
\text { Varians } \\
\text { Diekstrak } \\
\text { (AVE) }\end{array}$ \\
\hline $\begin{array}{l}\text { Organizational } \\
\text { culture }\end{array}$ & 0.925 & 0.932 & 0.941 & 0.729 \\
\hline $\begin{array}{l}\text { Employee } \\
\text { Performance }\end{array}$ & 0.944 & 0.948 & 0.958 & 0.820 \\
\hline Competence & 0.955 & 0.957 & 0.964 & 0.817 \\
\hline $\begin{array}{l}\text { Work } \\
\text { motivation }\end{array}$ & 0.887 & 0.888 & 0.917 & 0.689 \\
\hline
\end{tabular}

Table 1. Realibility and Validity constructs Source: Research Data Processing, 2021

The results of data processing for construct reliability testing can be seen in table 1 above. The results of Cronbach's Alpha value for each variable have a value of more than 0.6 , so it can be concluded that all variables are reliable or meet the reliability test. The magnitude of the indicator variance contained by the construct can be seen from the Average Variance Extracted (AVE) value. Based on the results in table 1. it can be seen that the AVE value of each variable has a value above 0.5 so that it can meet the convergent validity criteria (validity). The Composite Reliability value has a value above 0.7 , and it can be concluded that all constructs are reliable. 
Inner Model Test

a. Coefficient of Determination

\begin{tabular}{|l|r|r|}
\hline & \multicolumn{1}{|c|}{ R Square } & \multicolumn{1}{|c|}{ Adjusted R Square } \\
\hline Employee Performance & 0.850 & 0.837 \\
Work motivation & 0.367 & 0.350 \\
\hline
\end{tabular}

Table 2. Coefficient of Determination $\mathbf{R}^{2}$

Source: Research Data Processing, 2021

From table 2, the results of the coefficient of determination data or the value of $R$ Square (R2) for employee performance are 0.850 . This means that employee performance is influenced by competence, organizational culture, and work motivation by $85 \%$, while the remaining $15 \%$ is influenced by other factors not examined in this study. The value of $R$ square (R2) for work motivation is 0.367 , which means that work motivation is influenced by competence by $36.7 \%$, while other factors outside this study influence the remaining $63.3 \%$.

b. Hypothesis test

\begin{tabular}{|l|r|r|r|r|r|} 
& Sampel Asli (O) & Rata-rata Sam... & Standar Devias... & T Statistik (| O/... & P Values \\
\hline Budaya Organisasi -> Kinerj.. & 0.439 & 0.426 & 0.142 & 3.099 & 0.002 \\
\hline Kompetensi -> Kinerja Pega... & 0.317 & 0.320 & 0.145 & 2.194 & 0.029 \\
\hline Kompetensi -> Motivasi Kerja & 0.605 & 0.629 & 0.088 & 6.849 & 0.000 \\
\hline Motivasi Kerja -> Kinerja Pe... & 0.255 & 0.263 & 0.131 & 1.941 & 0.053 \\
\hline
\end{tabular}

Table 3. Path Coefficients

Source: Research Data Processing, 2021.

\section{Discussion}

\section{Hypothesis Testing 1}

H1: Competence has a positive and significant effect on work motivation

The influence of competence on employee performance can be seen from the original sample value of 0.605 with a positive sign, which means that competence positively affects work motivation. This result means that the better the competence, the better the employee's work motivation. Based on table 3 , the P-Value value is $0.000<0.05$ or with a T statistic of $6.849>$ 1.96 then $\mathrm{H} 1$ is accepted. This means that competence has a positive and significant effect on employee performance.

\section{Hypothesis Testing 2}

H2: Competence has a positive and significant effect on employee performance

The influence of competence on employee performance is indicated by the original sample value of 0.317 with a positive sign, which means that competence positively affects employee performance. This result means that the better the competence, the better the employee's performance. Based on table 3, the P-Value value is $0.029<0.05$ or with a T statistic of $2.194>$ 1.96 then $\mathrm{H} 2$ is accepted. This means that competence has a positive and significant effect on employee performance 


\section{Hypothesis Testing 3}

H3: Organizational Culture has a positive and significant effect on employee performance The influence of organizational culture on employee performance can be seen from the original sample value of 0.439 with a positive sign, which means that organizational culture has a positive effect on employee performance. This result means that the better the organizational culture, the better the employee's performance. Based on table 3, the P-Value value is $0.002<$ 0.05 or with a T statistic of $3.099>1.96$ then $\mathrm{H} 3$ is accepted. This means that organizational culture has a positive and significant effect on employee performance.

\section{Hypothesis Testing 4 \\ H4: Work motivation has a positive and significant effect on employee performance}

The effect of work motivation on employee performance can be seen from the original sample value of 0.255 . Based on table 3 , the P-Value value is $0.053>0.05$ or with a T statistic of 1.941 $<1.96$, then $\mathrm{H} 4$ is rejected. This means that work motivation has no effect and is not significant on employee performance.

\section{Conclusion}

Based on hypothesis testing by statistical means on the effect of each independent variable on the dependent variable, the following conclusions can be drawn:

1. Competence has a positive and significant influence on work motivation. The conclusion is based on the T Statistics value of $6.849>1.96$ and the P-Value of $0.000<0.05$. This means that the competence is getting better, the motivation to work will increase.

2. Competence has a positive and significant impact on employee performance. The conclusion is based on the T Statistics value of $2.194>1.96$ and the P-Value of $0.029<0.05$. This shows that with better competence, employee performance will increase.

3. Organizational culture has a positive and significant influence on employee performance. The conclusion is based on the T Statistics value of $3.099>1.96$ and the P-Value of $0.002<$ 0.05 . This shows that the better the organizational culture, the employee's performance will increase.

4. Work motivation has no effect and is not significant on employee performance. The conclusion is based on the T Statistics value of $1.941<1.96$ and the P-Value of $0.053>$ 0.05 . This means that work motivation does not affect employee performance.

\section{Suggestion}

Based on the research results, it can be used as a reference for agencies in improving employee performance so that all planned work can be realized. The influence of competence on work motivation has a positive influence, so increasing employee competence will increase work motivation, improving employee performance. Good competence will have a good influence on the final result of a job. The competence that supports the work will be able to be carried out following the targets that have been determined so that it will be able to improve government performance and meet the performance indicators that have been set.

Organizational culture also has a good influence on employee performance. Organizational culture needs to be improved to make it even better. A firm leadership attitude will help in promoting a good culture. Because with the support from the leadership, employees will always follow the organizational culture so that work activities will be realized following the plans that have been prepared.

Based on the research, work motivation does not affect employee performance. Based on this, it is necessary to support both the leader or co-workers so that the atmosphere in the work environment can make employees feel comfortable and motivated so that employees will be more enthusiastic at work. There needs to be an evaluation from the leadership regularly about what employees have achieved at work. Evaluating and input from the leadership will increase employee motivation because employees feel cared for by their leaders, so they will be more motivated to work. 


\section{References}

[1] N. Jalinus, R. A. Nabawi, and A. Mardin, "The seven steps of project based learning model to enhance productive competences of vocational students," 2017.

[2] V. G. Kondalkar, Organizational behaviour. New Age, 2020.

[3] M. Deni, "Kedisiplinan dan Motivasi Terhadap Kinerja Pegawai Pelayanan Publik," J. Manaj. dan Bisnis Sriwij., vol. 16, no. 1, pp. 31-43, 2018.

[4] P. T. Nguyen, A. Yandi, and M. R. Mahaputra, "Factors that influence employee performance: motivation, leadership, environment, culture organization, work achievement, competence and compensation (A study of human resource management literature studies)," Dinasti Int. J. Digit. Bus. Manag., vol. 1, no. 4, pp. 645-662, 2020.

[5] T. Pritvorova, B. Tasbulatova, and Y. Petrenko, "Possibilities of blitz-psychograms as a tool for human resource management in the supporting system of hardiness of company," Entrep. Sustain. Issues, vol. 6, no. 2, p. 840, 2018.

[6] N. Zacharakis et al., "Immune recognition of somatic mutations leading to complete durable regression in metastatic breast cancer," Nat. Med., vol. 24, no. 6, pp. 724-730, 2018.

[7] H. A. Dhahad, H. M. Hussen, P. T. Nguyen, H. Ghaebi, and M. A. Ashraf, "Thermodynamic and thermoeconomic analysis of innovative integration of Kalina and absorption refrigeration cycles for simultaneously cooling and power generation," Energy Convers. Manag., vol. 203, p. 112241, 2020.

[8] B. Pujiono, M. Setiawan, and R. Wijayanti, "The effect of transglobal leadership and organizational culture on job performance-Inter-employee trust as Moderating Variable," Int. J. Public Leadersh., 2020.

[9] N. M. S. Utami and I. A. M. Wedasuwari, "Determinants of teacher performance and education power through work motivation, learning leadership, and organizational culture," Int. J. Sustain. Educ. Glob. Creat. Econ., vol. 2, no. 2, pp. 13-20, 2019.

[10] E. E. W. Cohen et al., "Pembrolizumab versus methotrexate, docetaxel, or cetuximab for recurrent or metastatic head-and-neck squamous cell carcinoma (KEYNOTE-040): a randomised, open-label, phase 3 study," Lancet, vol. 393, no. 10167, pp. 156-167, 2019.

[11] I. Sapta, M. MUAFI, and N. M. SETINI, "The role of technology, organizational culture, and job satisfaction in improving employee performance during the Covid-19 pandemic," J. Asian Financ. Econ. Bus., vol. 8, no. 1, pp. 495-505, 2021.

[12] S. Prayetno and $\mathrm{H}$. Ali, "The influence of work motivation, entrepreneurship knowledge and advocate independence on advocate performance," Int. J. Innov. Creat. Chang., vol. 12, no. 3, pp. 147-164, 2020.

[13] E. Wuryani, A. Rodlib, S. Sutarsib, N. Dewib, and D. Arifb, "Analysis of decision support system on situational leadership styles on work motivation and employee performance," Manag. Sci. Lett., vol. 11, no. 2, pp. 365-372, 2021.

[14] I. Q. Fajrin and H. Susilo, "Pengaruh Gaya Kepemimpinan Terhadap Kinerja Karyawan Dengan Motivasi Kerja Sebagai Variabel Intervening (Studi pada Karyawan Pabrik Gula Kebon Agung Malang)," J. Adm. Bisnis, vol. 61, no. 4, pp. 117-124, 2018.

[15] A. Werdhiastutie, F. Suhariadi, and S. G. Partiwi, "Achievement Motivation as Antecedents of Quality Improvement of Organizational Human Resources," Int. Res. Critics Institute-Journal, pp. 747-752, 2020.

[16] F. Febianti and T. M. Nurwan, "THE EFFECTS OF ORGANIZATIONAL CULTURE ON EMPLOYEE PERFORMANCE IN SUMEDANG SELATAN DISTRICT OFFICE SUMEDANG REGENCY," JHSS (JOURNAL Humanit. Soc. Stud., vol. 5, no. 1, pp. 610, 2021.

[17] A. D. Hardiani and A. Prasetya, "Pengaruh Kepercayaan Organisasional dan Kompetensi Terhadap Kinerja Karyawan Melalui Motivasi Kerja (Studi Pada Karyawan PT. PLN Persero Distribusi Jawa Barat Area Bekasi)," J. Adm. Bisnis, vol. 61, no. 3, pp. $1-9,2018$.

[18] A. P. Harahap, F. Siregar, and A. Aligami, "PENGARUH KEPEMIMPINAN DAN KOMPETENSI DENGAN MOTIVASI KERJA SEBAGAI VARIABEL INTERVENING TERHADAP KINERJA PEGAWAI DI KEMENTERIAN AGAMA KABUPATEN PADANG LAWAS UTARA," JRMB (Jurnal Ris. Manaj. dan Bisnis), vol. 5, no. 2, pp. 175-184, 
2020.

[19] R. Sabuhari, A. Sudiro, D. Irawanto, and M. Rahayu, "The effects of human resource flexibility, employee competency, organizational culture adaptation and job satisfaction on employee performance," Manag. Sci. Lett., vol. 10, no. 8, pp. 1775-1786, 2020.

[20] W. Wahyudi, "The Influence of Emotional Intelligence, Competence and Work Environment on Teacher Performance of SMP Kemala Bhayangkari Jakarta," Sci. J. Reflect. Econ. Accounting, Manag. Bus., vol. 1, no. 2, pp. 211-220, 2018.

[21] S. L. Ratnasari, M. M. SE, and Y. Hartati, Manajemen Kinerja Dalam Organisasi. Penerbit Qiara Media, 2019.

[22] A. Purwanto, M. Asbari, and P. B. Santoso, "Does Culture, Motivation, Competence, Leadership, Commitment Influence Quality Performance?," Inovbiz J. Inov. Bisnis, vol. 7, no. 2, pp. 201-205, 2019.

[23] A. Waheed, X. Miao, S. Waheed, N. Ahmad, and A. Majeed, "How new HRM practices, organizational innovation, and innovative climate affect the innovation performance in the IT industry: A moderated-mediation analysis," Sustainability, vol. 11, no. 3, p. 621, 2019.

[24] Y. Dharma, "The effect of work motivation on the employee performance with organization citizenship behavior as intervening variable at Bank Aceh Syariah," in Proceedings of MICoMS 2017, Emerald Publishing Limited, 2018.

[25] I. PANCASILA, S. HARYONO, and B. A. SULISTYO, "Effects of work motivation and leadership toward work satisfaction and employee performance: Evidence from Indonesia," J. Asian Financ. Econ. Bus., vol. 7, no. 6, pp. 387-397, 2020.

[26] H. Latan, C. J. C. Jabbour, A. B. L. de Sousa Jabbour, S. F. Wamba, and M. Shahbaz, "Effects of environmental strategy, environmental uncertainty and top management's commitment on corporate environmental performance: The role of environmental management accounting," J. Clean. Prod., vol. 180, pp. 297-306, 2018. 